\title{
THE POLICY OF RENEWABLE ENERGY SOURCES IN THE FUNCTION OF THE ENVIRONMENTAL PROTECTION IN THE EU
}

\author{
Dejan Ž. Đorđević \\ University of Niš, Faculty of Economics, Serbia \\ $\bowtie 565$ geo@gmail.com
}

\section{Milan Veselinović}

Higher economic school of professional studies Peć, Leposavić, Serbia

\section{UDC}

620.9:502

(4-672EU)

Review paper

Received:

01.4 .2015

Accepted:

24.9.2015

\begin{abstract}
The policy of renewable energy sources has gained more importance over recent years. The European Union is facing serious challenges regarding greenhouse gas emissions and energy sustainability, followed by the supply security, import dependence and competitiveness as well as the effective implementation of the internal energy market. The energy policy of the European Union is the most effective response to the new situation the member states of the European Union are facing. The EU energy policy aims to cause a new industrial revolution and the growth of the economic energy efficiency with low emissions of carbon dioxide. In order to achieve this, targets have been set for the future. Among them is the increase in the share of production and consumption of renewable energy in the total energy balance.
\end{abstract}

Keywords: renewable energy sources, energy policy of the EU, environmental protection, energy efficiency

\section{Introduction}

The issue of energy security and stability is certainly an important question of the entire socio-economic system, and renewable energy sources, with their characteristics, are the logical alternative to a rational solution. In addition, it is important to mention environmental pollution and the greenhouse effect caused by the emission of harmful gases in recent decades, which take a toll in the form of the drastic changes in weather conditions around the world. Nowadays, the European Union is facing serious challenges regarding greenhouse gas emissions and energy sustainability, followed by the supply security, import dependence and the competitiveness and effective implementation of the 
internal energy market. The best current response to the new situation the member states of the European Union are facing is its energy policy.

The energy policy of the European Union aspires to a new industrial revolution and the growth of the economic energy efficiency with low emissions of carbon dioxide. EU firmly commits its institutions to implement rational energy consumption, based on a more secure and competitive energy market, which would be in the function of sustainable energy. The main objectives of the EU energy policy include ensuring safe functioning of the internal market in the field ofenergy, the security of strategic supply, the radical reduction of greenhouse gas emissions caused by energy production and consumption as well as to allow its institutions to perform together on the international scene.

\section{A strategic approach to environmental protection}

Ensuring the functioning of the internal energy market is a priority because consumers should have a choice in the energy supply at fair and competitive prices. In this context, it is clear that there should be a strict separation between the management of the production and distribution sectors in the energy market. ${ }^{1}$

The internal energy market, in fact, depends on cross-border cooperation and energy trade. However, in order to avoid discrepancy between the regulations of national technical standards and differences in network capacity, a more effective regulation at the EU level is required. The competence and independence of regulatory institutions should be harmonized, their cooperation strengthened and their efforts should be more efficient in the field of the harmonization of common technical standards, quality, development of infrastructure and network capacity, system security, consumer protection and promotion of programs aimed at cross-border cooperation.

The new energy policy of the European Union puts the emphasis on the measures which ensure the solidarity between member states and the diversification of supply sources and transport routes. This will provide a more secure energy supply and reduce the uncertainty regarding imported energy supply, the decline in the supply and the emergence of an energy crisis.

Today, many countries in the world, apart from the European Union, notably Japan, the USA and Australia, have determined the directions of their energy policies with their directives, which include the increased use of renewable energy in the next 20 to 30 years, both for the purpose of diversifying the risk of dependence on imported energy and the environmental protection.

\footnotetext{
${ }^{1}$ If a company controls the network management as well as production or sales, there is a serious risk of discrimination. A vertically integrated company has little interest in increasing the network capacity, thereby exhibiting increased competition in the market and decreasing prices.
} 
The energy policy of the European Union is dedicated to the reduction of greenhouse gas emissions by at least $20 \%$ by 2020 . It also calls on the conclusion of an international agreement which will oblige developed countries to reduce their emissions of greenhouse gases by $30 \%$ by 2020 . Under this agreement, the EU has set itself a new target to reduce greenhouse gas emissions by $30 \%$ compared to the level in 1990 . These objectives are at the heart of the EU's strategy for limiting climate change. Of course, the reduction of greenhouse gas emissions implies savings in energy consumption and more use of "clean" energy.

"Faced with the problems of environmental impact and energy stability issues, the EU has accepted the obligations of the Kyoto Protocol and covered them with its energy policy. Thus, the EU strategy aims to reduce greenhouse gas emissions by $80-95 \%$ compared to 1990 levels by 2050 . This is in line with the position supported by leaders in the Copenhagen and Cancun agreements. It is expected that the energy efficiency and switching to domestic sources of energy with low carbon content will reduce the average cost of fuel for the EU between 175 and 320 billion euros annually. Towards the mitigation of climate change, there will be less need for imports of fossil fuels, and fuel costs that will continue to be imported will be reduced " (White Paper, 2011).

\section{Renewable energy sources, energy saving and environmental protection}

The current situation in the international oil market and the increasing timeliness of renewable energy sources are clearly closely linked. Therefore, the policy of using renewable energy sources in recent years has gained more and more importance. Although over the last three decades more attention has been paid to the policy of using alternative energy sources, from the onset of the economic and energy crisis of 2008, alternative energy sources, particularly renewable, are increasingly gaining in importance.

Since the EU is now dependent on imported energy, especially oil, but is also a large producer of greenhouse gases, its policy is going in two directions: the rational use of energy by using energy efficiency measures and the replacement of fossil fuels by renewable energy sources (hereinafter referred to as RES) .

"Saving and rational use of energy by applying energy efficiency measures is aimed at many industrial sectors such as transport (26\%), construction (27\%), industrial and municipal energy $(25 \%)$ and so on. It is estimated that the total final energy savings can reach $30 \%$ by 2020 . In this way up to $390 \mathrm{Mtoe} /$ year $^{2}$, or about 100 billion euros annually can be saved by 2020 . Also, it is estimated that carbon dioxide emissions would be reduced by 780 million tons per year due to these savings " (Đereg et al., 2008).

\footnotetext{
${ }^{2}$ mtoe - million tons of oil equivalent
} 
Under the new energy policy, the European Union has set itself the target to reduce its energy consumption by $20 \%$ by 2020 in its Action Plan for Energy Efficiency (2007-2012). Significant investments and efforts to achieve this goal are expected, especially in terms of energy savings in the transport sector, the development of minimum efficiency requirements when using electrical appliances, raising awareness among consumers concerning reasonable and economical use of energy, improving the production efficiency, transmission and distribution of electricity and heating and the development of energy technologies that improve the energy characteristics of buildings. Among them is the increase in the share of production and consumption of renewable energy sources in the total energy balance. Also, there is the goal to increase the share of renewable energy sources by $20 \%$ by 2020 . This objective should be achieved in three sectors (Smarter, greener more inclusive, 2015):

1. through increasing the electricity production from renewable energy sources, which also supports the policy of sustainable production of electricity from fossil fuels;

2. increasing the production of biofuels, which would be used by at least $10 \%$ of the vehicles in the EU;

3. through savings in heating and cooling systems of buildings around the EU as well as using electricity from RES

As the European Union included the goal to reduce energy consumption by an average of $20 \%$ by 2020 in its Action Plan for Energy Efficiency (20072012), at the same time options for achieving the set goal were discussed. This plan was designed as a series of short-term and medium-term measures (raising awareness concerning energy conservation, the application of certain standards for the energy efficiency of certain devices, the development of new technologies, financial and fiscal incentives). Although the set objectives and investments for the given period are not fully implemented, what has been done until present day is not insignificant. The regulatory framework regarding consumption, investment, taxation and the development of consumerawareness has been set. Their application, taking into account the complexity of the problem, is not easy and takes time.

The largest consumer of energy is the transport sector (20\%). With the highest rate of growth in consumption, traffic is a major risk to the environment and is one of the main factors of import dependence on fossil fuels. The EU Commission set the threshold of $130 \mathrm{~g} / \mathrm{km}$ of CO2 (instead of the planned 120 $\mathrm{g} / \mathrm{km}$ ) in order to reduce emissions of pollutants from cars. Steps have been taken to promote "clean" alternative transportation in order to influence public awareness regarding clean energy and energy-saving. Many EU member states still make efforts in the procurement of the vehicles for public transport which consume "clean" energy, the adoption and implementation of legal regulations 
that promote "eco" vehicles, as well as the pressure and resistance regulation in the tires of vehicles (Mihajlovic, Veselinovic, 2013).

In the last decade, the production and use of alternative, ecological fuels has been significantly intensified. In all the regions of the world more attention is paid to the production and use of bio-alcohol and biodiesel as well as other alternative fuels. The increase in the ethanol production in the world is related to the use of ethanol as an alternative, or "clean" fuel. According to data from 2011, the number of countries that produce ethanol increased to 13 and, according to forecasts, significant investments are expected in the European Union, the USA, Brazil, India, Thailand, China, Australia and Japan. The reason for the global trend of the increasing use of ethanol-based fuels, among other things, is that ethanol has a positive net energy balance, which means that the energy contained in a ton of ethanol is greater than the energy needed to produce it. ${ }^{3}$ According to the Action Plan, refineries are to be built, which will produce sufficient quantities of biofuels used to significantly increase savings in the fuel consumption in the transportation sector (10\%). Reducing energy consumption in the EU is facing other modes of transport, such as rail, air and water transport.

By producing high-quality building materials in industry and their use in construction, according to the prescribed standards, energy savings of $45 \%$ will be achieved by 2020. Ecological buildings represent the future of the European Union. The realization of such projects require large investments, high level of expertise and developed technology. Modern engineering prefers modern construction projects which use renewable energy sources for their energy needs (Picture 1).

On the other hand, the whole process includes domestic and foreign financial factors that meet the requirements of many projects with their financial arrangements. Private banking sector, the IMF, the European Bank for Reconstruction and Development, European Investment Bank and other financial institutions can facilitate the achievements of such set goals. The banking sector across the EU already offers favorable financial packages for small and medium enterprises in order to increase energy efficiency and energy savings. The benefits of such form of business are numerous: lower taxes and favorable loans for enterprises, lower taxes for banks, energy savings and less import dependence for the country.

\footnotetext{
${ }^{3}$ According to the London scientist Dr. Mae Non Hou, Brazilian bioethanol program was initiated at the time of the great oil crisis of the seventies and has been the most important market of biofuels in the world for decades. In Brazil there are 300 bioethanol refineries, and more than 60 are under construction, and biodiesel from soybeans is produced. Approximately $50 \%$ of the total yield of sugar cane is processed into ethanol, and over 30 thousand bioethanol stations were opened. Brazil currently produces around 15.9 billion liters of bioethanol.
} 
Picture1. The Tower "Lighthouse" in Dubai has 4.000 solar panels on the south side and three wind turbines, which meets its own energy needs

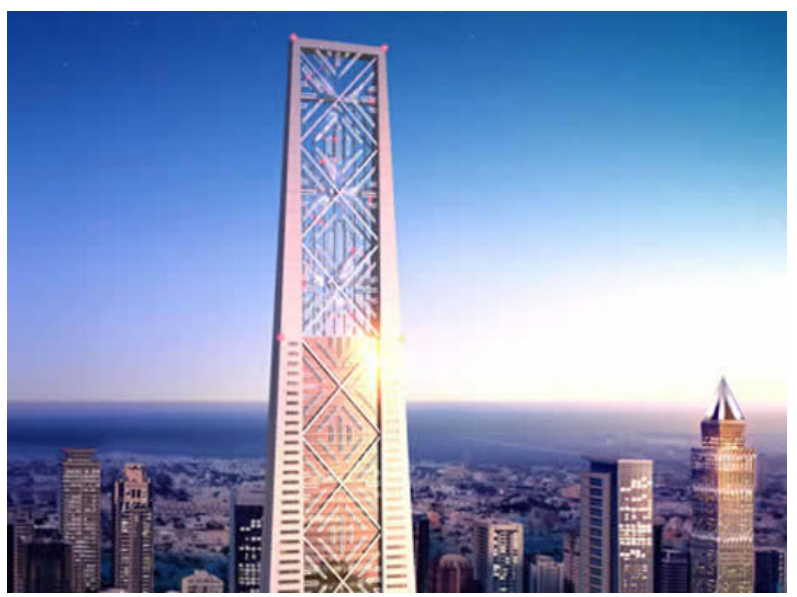

Another direction which the EU energy policy is facing is to reduce the use of fossil fuels and replacing them with RES, which are available within the EU. This approach contributes to the reduction of import dependence, environmental protection and reducing greenhouse gas emissions, implementation and export of new technologies, investments and new workplaces, i.e. the so-called "3E effect" in the field of energy, ecology and economy. The plan is that the use of renewable energy by 2020 will achieve a positive effect in the amount of $3 \times 20 \%$ in all three segments. The overall approach is based on specific directives. ${ }^{4}$ On the basis of these, European regulations are aimed at promoting renewable energy and energy efficiency, security of supply, environmental protection and strengthening of the common market. Each member of the EU is obliged to increase the share of renewable energy in its own electricity production by 2020 and to set a goal to which extent RES is to take part in total consumption. By producing energy from RES, Germany and other EU member states (Belgium, Austria, etc.) slowly turn their backs on nuclear power plants, as the adopted measures (e.g. feed-in tariffs) eventually began to give significant results, especially when it comes to the production of electricity from the energy of wind and sun.

\footnotetext{
${ }^{4}$ Directive 2001/77 / EC- on the promotion of electricity produced from renewable energy sources in the international electricity market; Directive 2003/30 / EC on the promotion of the use of biofuels or other renewable fuels for transport; Directive 2001/80 / EC- on the limitation of emissions into the air from large combustion plants; Directive 1999/32 / ECD - on the reduction of the sulfur content of liquid fuels; and Directive 96/61 / EC- on Integrated Pollution Prevention and Control so. "IPPC Directive" (Smarter, Greener more inclusive, 2015)
} 
The unavoidable path to quickly achieving the goals set by the EU member states is to introduce economic instruments to encourage investments in renewable energy. Some of these tools are privileged price systems (known as the "feed-in" tariffs) and green certificates trading system combined with mandatory quotas.

In the green certificate trading system, each manufacturer is issued a green certificate for each MWh produced from RES which can be traded with on the market, so that each manufacturer can meet their quota of the government. This approach is applicable in the United Kingdom, Romania and the Czech Republic. It is based on the selection and implementation of commitments to produce a minimum proportion of electricity from RES. "In the event of fault, fines may be applied, and for more efficient use of the system of quotas, programs of issuing green certificates that can be traded with are applied. This approach can be supplemented by other measures if the positive effect is expected. Thus, the Czech Republic adopted a dual support system, where producers of electricity from RES can choose between the traditional fixed preferential price and the market price complemened by fixed environmental (green) grants on the basis of the Kyoto Protocol. Environmental grants are fixed for the next year depending on the RES (determined annually), so that the total amount of fees to the amount of expected average selling prices is higher than the fixed selling price, which is consistent with the increased risk " (Đereg et al. 2008).

In the system of privileged priced, the purchase price for electricity obtained from each renewable source is determined. The system of privileged prices is often applied more often, which does not mean that it is economically more efficient in its approach, but it is recognized by investors as a sign of security because it is transparent, easy to administer and flexible. As an effective instrument for achieving sustainable goals, it is best illustrated in the example of Germany, in the field of wind energy production. By applying the law on privileged prices in 2007 , Germany produced $14.2 \%$ of electricity from renewable energy sources, and the government of Germany calculated that in the same year it saved 57 million tons of $\mathrm{CO}_{2}$.

The aim was to encourage investments and achieve savings from technical progress. Germany achieved great success in the development of electricity generation using RES, primarily wind and solar energy, not only by the introduction of preferential tariffs, but also by the will of consumers to accept such cost, as well as through the gradual equalization of electricity prices from different sources of redistribution, and whose burden is born by manufacturers themselves. The German system of preferential tariffs is a good example of cost accounting. The price per KWh of electricity is fixed for the companies that belong to the system, but is determined by the year of work commencement. The longer the company is connected to the system, the lower is the price, in line with the decrease rate.Tariffs are obtained on the basis of cost estimates. 
Prices vary depending on the degree of load and the amount of compensation to the producers of electricity (wind, solar, hydro, etc.). The less attractive the location, the higher the price, and vice versa. This rate of price calculation is legally introduced in order to standardize the conditions for the balanced development of RES on the whole territory (Mihajlovic, Veselinovic, 2013).

The energy policy of the European Union, as well as the energy policy of the leading economies in the world are without prejudice in compliance with the international energy policy, UN policy on environmental protection and global tendencies and trends 5 . At the United Nations Conference on Environment and Development ("UNCED"), held in 1992 in Brazil, which was attended by 10,000 representatives from 150 countries the Action Plan for Sustainable Development for XXI (Agenda 21) was adopted, which contains 27principles. ${ }^{6}$

The data below clearly show that the share of renewable energy in the total energy consumption of the European Union gradually increased. The share of renewable energy in 2005 in the total energy consumption of the EU amounted to $8.6 \%$. Five years later, the share increased by one-third, and in 2010 was $12 \%$. According to EUROSTAT report, the share in the next two years grew by $1.1 \%$ and the total share in 2012 amounted to $14.2 \%$. Several EU countries have already achieved the goals regarding their participation for 2020 .

Table 1: Share of RES in the EU (2005-2009)

\begin{tabular}{||c|c|c|c|c|c||}
\hline eu-27 & $\mathbf{2 0 0 5}$. & $\mathbf{2 0 0 6}$. & $\mathbf{2 0 0 7 .}$ & $\mathbf{2 0 0 8}$. & $\mathbf{2 0 0 9 .}$ \\
\hline Share of RES & $8.6 \%$ & $8.8 \%$ & $9.7 \%$ & $10.3 \%$ & $11 \%$ \\
\hline $\begin{array}{c}\text { Final Energy } \\
\text { Consumption (Mtoe) }\end{array}$ & 1,182 & 1,186 & $1,164.8$ & $1,168.6$ & 1,074 \\
\hline $\begin{array}{c}\text { RES Final Energy } \\
\text { Consumption (Mtoe) }\end{array}$ & 101.6 & 104.3 & 112.9 & 120.4 & 118.1 \\
\hline
\end{tabular}

Source: EREC based on Eurostat

In absolute figures, in 2005 the consumption of renewable energy amounted to 103 Mtoe and gradually increased annually by an average of 10 to 20 Mtoe

\footnotetext{
${ }^{5}$ Organized by the UN Convention on Climate Change ("UNFCC"), the protocol opened for signing in the Japanese city of Kyoto on 11.12.1997. To come into force, it was necessary to be signed by 55 countries, and that the countries which sign it represent $55 \%$ of pollutants in the world. The objective of the UN Framework Convention is to stabilize greenhouse gas concentrations at a level that would not affect the climate system. The Protocol was established by the UN Convention on Climate Change ("UNFCCC"), which includes most of the world except the United States and Australia. It is officially the first legal contract, and so far it has been signed by 170 countries and governmental organizations. The Protocol entered into force on 16.2. 2005, when it was ratified by Russia. The countries that have ratified it consist of $61 \%$ of pollutants. Although the number of countries that have ratified the Kyoto Protocol increased, climate change is increasing, as well as global warming. Countries outside the protocol also tend to reduce the concentration of greenhouse gases (Mihajlovic, Veselinovic, 2013)

In the context of multilateral agreements in the field of environment, important issues are the Convention on the access to information, public participation and decision-making process and the access to legal bodies in the field of environmental protection ("Aarhus") and the Convention on the assessment of transboundary environmental impact ("Epoo" "IEA ")
} 
per year to date. The plan is that the total consumption of renewable energy has a share in gross final energy consumption of 217 Mtoe.

\section{Conclusion}

The need for bypassing the problem of exhaustion of non-renewable natural resources, especially when it comes to fossil fuels, is evident, and operating materials, which do not require modification of existing power machines, are gaining more and more importance. This especially applies to the period when significant hits occurred on the liquid fossil fuel marke,t as they were recorded in 2008 and 2014. In the last decade, in addition to solar and wind energy, the production and use of alternative, ecological fuels has been significantly intensified. ${ }^{7}$ In all the regions of the world more and more attention is paid to the production of bio-alcohol and biodiesel as well as other alternative fuels. The selection of raw materials has been expanded to include substances that contain carbohydrates or fats of any vegetable or animal origin. Recycling waste fat is particularly important in the view of the potential dangers of its uncontrolled spill into waterways or of its use as animal feed, which is prohibited in many countries. Unlike fossil energy sources, this kind of energy does not take millions of years to form coal or oil. Organic material which occurs during the growing season can immediately be converted into energy which goes on constantly. Biomass burning releases carbon - dioxide, exactly as much as it was absorbed into organic material during the growing season. On the other hand, the emergence of substitute oil and its increasing exploitation, was largely influenced by the unstable and growing price of crude oil in the market. Thus, we can say that there is a mutual influence between the oil price and the appearance of its substitutes. The importance of renewable energy sources, in this context, is that they affect the price of fossil fuels, primarily the price of oil, by changing the ratio of supply and demand in the long term. Since RES are to be increasingly used, so will the demand for oil decrease, which will ultimately affect its lower price. In other words, the price of oil today would be much higher if RES did not exist, i.e. if it was not used.

Although the countries of the European Union had favorable conditions and time to implement regulations relating to the use of RES in energy purposes, from a stable economic and political system, investments, technological advantages, to a higher level of awareness regarding the benefits of renewable energy compared to non-renewable, many member states have failed to realize their set goals completely. It is certainly not for criticism nor is it surprising, given the complexity of the problem and the level of the goals.

7 The ethanol based fuel comply with the essential conditions for unlimited use: can be used to drive the internal combustion engine; their combustion does not generate harmful products and are ecologically safe; chemical means can provide a wide range of products that are now exclusively derived from petroleum; they are particularly important for the production of environmentally friendly anti-knock socalled ETBE (etil tertiary butyl ether); have a wider application in the pharmaceutical industry. 


\section{References}

Recap budget renewable energy potential Republic of Serbia (2007), Faculty of Technical Science, Institute for Energy and Process Enginering, Novi Sad

Organization of Petroleum Exporting Countries (2010), Annual raport, preuzeto sawww.opec.org/annualraport

White Paper (2011), Public Enterprise "Electric Power Industry of Serbia", Department of Public Relations, preuzeto sa www.eps.rs

Djereg N., Jović K. K. Z., Ionut A. (2008), Renewable Energy - referrals, resources and criteria, Centre for Ecology and Sustaniable Development, The project "Towards sustianable energy in South East Europe", CEE Bankwatch Network in Serbia, Subotica

Interbational Energy Agency (2009), Annual raport, preuzeto sawww.iea.doe.gov.site

Stosić-Mihajlović Lj. (2008), The Possibility of Improving the Energy Efficiency of Buildings Through the Certification Process, Management, Innovation and Development, Institute if Serbian invent the Institute for Solar Energy, Vrnjačka Banja

Stošić-Mihajlović Lj. (2008), Energy Efficiency and use Renewable Energy Sources as Environmental Imperative in the Development of Modern Urban Village, Institute for Solar Energy, Vrnjacka Banja

Stošić-Mihajlović Lj. (2010), Sustianable Economic Development and Green Energy, International Conference Environment and Biodiversity, Science Journal Ecologica, Belgrade

Zdravković D., Radukić S.,Veselinovic M. (2011), Impact of economic and energy crisis on the problem of indebtedness, Science gatering, Kosovska Mitrovica

Mihajlović Lj., Veselinović M. (2013), Utilization of renewable energy sources in EU, Science gatering, Belgrade

Veselinović M. (2011), Cena nafte i njen uticaj na privredu Republike Srbije, Magistarski rad, Ekonomski fakultet, $\mathrm{Niš}$

Smarter, greener more inclusive? (2015), Indicators to support the Europe 2020 strategy, Eurostat statistical books, preuzeto sa www.ec.europa.eu

www.europa.eu, visited 03. 01. 2015

www.inhabitat.com, visited 03. 01. 2015

\section{POLITIKA KORIŠĆENJA OBNOVLJIVIH IZVORA ENERGIJE U FUNKCIJI ZAŠTITE ŽIVOTNE SREDINE U EU}

Apstrakt: Politika korišćenja obnovljivih izvora energije, poslednjih godina, dobija sve više na značaju. Evropska unija se suočava sa ozbiljnim izazovima oko emisije gasova staklene bašte i energetske održivosti, zatim sigurnosti snadbevanja, uvozne zavisnosti i konkurentnosti, kao i efikasne implementacije unutrašnjeg energetskog tržišta. Kao najefikasniji odgovor na novonastalu situaciju, sa kojom se suočavaju zemlje članice Evropske unije, jeste njena energetska politika. Energetska politika Evropske unije ima za cilj da dođe do nove industrijske revolucije i rasta energetske efikasnosti privrede sa niskom emisijom ugljendioksida. Kako bi se to postiglo, postavljeni su ciljevi koje u budućnosti treba u velikoj meri realizovati. Među njima je i povećanje udela proizvodnje i potrošnje obnovljivih izvora energije u ukupnom energetskom bilansu.

Ključne reči: obnovljivi izvori energije, energetska politika EU, zaštita životne sredine, energetska efikasnost 